UDC 005.7

DOI 10.33082/2226-1893-2019-3-140-155

\title{
BENCHMARKING MODEL BASED ON GENETIC MECHANISMS IN PROJECT MANAGEMENT
}

\author{
L.S. Chernova \\ Ph.D., Doctoral student \\ of the Department of «Information Control Systems and Technologies» \\ 19chls92@gmail.com
}

Nikolaev University of Shipbuilding them. Admiral Makarov, Nikolaev, Ukraine

\begin{abstract}
The application of knowledge accumulated in the fundamental mechanisms of wildlife is a global trend in the development of project management. This trend requires additional research on the development of existing methodologies, knowledge systems, and genetic mechanisms of project and program management. Convergence (oncoming) of knowledge systems of various branches and benchmarking are mechanisms that transfer knowledge and best practice between domains. The authors proposed a classification of convergence mechanisms for further transfer of knowledge - benchmarking between different domains. Four principles of constructing and developing methodologies for project management based on transfer of knowledge and best practice are formulated. These are the principles of the necessary diversity (Ashby), the coherence of methodologies, convergence, integration and harmonization, the focus on the result and product. They are given basic definitions and application of genetic models in creation of methodologies of project management. The model of application of genetic mechanisms of the matrix model of knowledge (mRNA), models and methods of project management is proposed. The benchmarking model of genetic mechanisms and information in project management is defined as a sequence of matrix RNA processing steps. The following steps that are described in the interpretation of project management methodologies are initiation, transcription, processing and transport, translation, splicing, modification, product formation, and termination. Considered approach has a significant impact on the development of the competence of project managers, taking into account the creation and production of fundamentally new knowledge and management mechanisms.

Keywords: genetic mechanism, benchmarking, classification of knowledge transfer mechanisms, principles of transfer of knowledge and development of methodologies, matrix RNA, processes of matrix RNA processing.
\end{abstract}

(C) Chernova L.S., 2019

УДК 005.7 
ВІСНИК

ОДЕСЬКОГО НАЦІОНАЛЬНОГО

МОРСЬКОГО УНІВЕРСИТЕТУ

№ 3 (60), 2019
HERALD

OF THE ODESSA NATIONAL

MARITIME UNIVERSITY № 3 (60), 2019

DOI 10.33082/2226-1893-2019-3-140-155

\title{
МОДЕЛЬ БЕНЧМАРКІНГУ НА ОСНОВІ ГЕНЕТИЧНИХ МЕХАНІЗМІВ В УПРАВЛІННІ ПРОЕКТАМИ
}

\author{
Л.С. Чернова \\ к.т.н., докторант \\ кафедри «Інформаційних управляючих систем та технологій» \\ 19chls92@gmail.com
}

Наџіональний університет кораблебудування ім. адмірала Макарова м. Миколаїв, Украӥна

\begin{abstract}
Анотація. Застосування знань накопичених у фундаментальних механізмах живої природи є глобальним трендом розвитку проектного управління. Цей тренд потребує додаткових досліджень щодо розвитку існуючих методологій, систем знань, генетичних механізмів управління проектами та програмами. Конвергенція (наближення) систем знань різних галузей та бенчмаркінг є механізмами які переносять знання та краму практику між предметними областями. Автори запропонували класифікацію механізмів конвергениії для подальшого переносу знань бенчмаркінгу між різними галузями. Сформульовані чотири принципи побудови та розвитку методологій управління проектами на основі переносу знань та кращої практики. Це принципи необхідного різноманіття (Ешбі), когерентності методологій, конвергениії, інтеграиії й гармонізаиії, наиіленості на результат та продукт. Наведені базові визначення застосування генетичних моделей у створенні методологій управління проектами. Запропоновано модель застосування генетичних механізмів матричної моделі знань (мРНК), моделей та методів управління проектами. Модель бенчмаркінгу генетичних механізмів та інформачї в управлінні проектами визначені у вигляді послідовності крокі обробки матричної РНК. Такими кроками, які описані у інтерпретації методологій управління проектами, є: ініціація, транскрипџія, процесінг $i$ транспорт, транслячія, сплайсінг, модифікачія, формування продукту та термінація. Розглянутий підхід має суттєвий вплив на формування компе-тентності проектних менеджерів з урахуванням створення та про-вадження принципово нових знань та механізмів управління.

Ключові слова: генетичний механізм, бенчмаркінг, класифікачія механізмів переносу знань, принципи переносу знань та розвитку методологій, матрична РНК, прочеси обробки матричної РНК.
\end{abstract}


ВІСНИК

ОДЕСЬКОГО НАЦІОНАЛЬНОГО

МОРСЬКОГО УНІВЕРСИТЕТУ

№ 3 (60), 2019
HERALD

OF THE ODESSA NATIONAL

MARITIME UNIVERSITY № $3(60), 2019$

УДК 005.7

DOI 10.33082/2226-1893-2019-3-140-155

\title{
МОДЕЛЬ БЕНЧМАРКИНГА НА ОСНОВЕ ГЕНЕТИЧЕСКИХ МЕХАНИЗМОВ В УПРАВЛЕНИИ ПРОЕКТАМИ
}

\author{
Л.С. Чернова \\ к.т.н., докторант \\ кафедры «Информационных управляющих систем и технологий» \\ 19chls92@gmail.com \\ Национальный университет кораблестроения ім. адмирала Макарова \\ г. Николаев, Украина
}

\begin{abstract}
Аннотация. Применение знаний накопленных в фундаментальных механизмах живой природы является глобальным трендом развития проектного управления. Этот тренд требует дополнительных исследований по развитию существующих методологий, систем знаний, генетических механизмов управления проектами и программами. Конвергенция (приближение) систем знаний различных отраслей и бенчмаркинг являются механизмами, которые переносят знания и лучшую практику между предметными областями. Авторы предложили классификацию механизмов конвергенции для дальнейшего переноса знаний - бенчмаркинга между различными отраслями. Сформулированы четыре принципа построения и развития методологий управления проектами на основе переноса знаний и лучшей практики. Это принципы необходимого разнообразия (Эшби), когерентности методологий, конвергенции, интеграции и гармонизации, нацеленности на результат и продукт. Приведенные базовые определения и применения генетических моделей в создании методологий управления проектами. Предложена модель применения генетических механизмов матричной модели знаний (мРНК), моделей и методов управления проектами. Модель бенчмаркинга генетических механизмов и информации в управлении проектами определены в виде последовательности шаге обработки матричной РНК. Такими шагами, которые описаны в интерпретации методологий управления проектами, являются: инициация, транскрипиия, процессинг и транспорт, трансляция, сплайсинг, модификачия, формирования продукта и терминация. Рассмотренный переход оказывает существенное влияние на формирование компетентности проектных менеджеров с учетом создания и производства принципиально новых знаний и механизмов управления.
\end{abstract}

Ключевые слова: генетический механизм, бенчмаркинг, классификация механизмов переноса знаний, принципы переноса знаний и развития методологий, матричная РНК, прочессы обработки матричной РНК. 
Introduction. Project management methodologies are now transformed into standards supported by various professional structures such as Individual competence baseline for Project, Programme and Portfolio management [1], Organisational Competence Baseline [2] and others. The standards became necessary for success of an organization in competitive struggle based on the strategy of efficient using intellectual assets to improve productivity and efficiency, and to create new values. Knowledge management is considered in the form of systemic processes, creation, storage, their distribution and migration. The praxis of nowadays does not have efficient structures of knowledge about the management methodologies. Therefore, the transfer of knowledge (benchmarking) from the wildlife to models, methods and mechanisms of project management becomes an important instrument of the project management development. The benchmarking allows bringing the knowledge of systems closer for their enrichment based on convergence. Convergence is a statement that whatever difference would be between management systems, they dispose of inefficient instruments and keep efficient ones in the process of their development. This makes them become relatively similar after such gradual selection. Development of knowledge and methodologies, engineering and techno-logy that reduce step by step the difference between management systems of various domains so creating the unified methodological basis with account taken of management objects peculiarity is another factor contributing to it to a significant extent.

Problem statement. The main hypothesis of the research is in the assumption that the efficiency of processes of transferring knowledge into the project management depends on the level of competence of organization and its managers. Therefore, the organizations have the following topical task: to develop the competence potential of specialists which is absolutely essential for taking correct management decisions and carrying out reliable expertise in the course of the project implementation based on the knowledge of methodology, best practices and lessons. However, it has to be kept in mind that for each employee building up personal career within an organization, such a development is, on one side, a motivating factor, and, on the other side, a threat. At the same time, it is expected from each employee to learn to manage his or her own competence and to develop it. Under the competence, we understand a set of behavior models, knowledge and skills of employees that help them to achieve better results as regards their key tasks on the position held by them and their role played within the organization. Competence - is not a behavior or a level of fulfillment as it is, but it a range of abilities, activity, processes and possible reactions that help some people to comply with works requirements better than the others. Successful implementation of innovative projects and programs in ensured by creative application of the competence approach [3]. Such approach can be used as a common language of communication uniting the organization and the employees, the tasks and the executors. 
In this case, development of the organization and development of the personnel take place simultaneously. In the reality, there is the same number of competences as the number of detailed activities that can be selected and adapted to own organizational processes, strategy and culture.

The modern science and practice of creating and developing methodologies in the project management show that each methodology is now formed from a clean sheet of paper. In this case, the same mistakes are made many times. In globally leading companies, the project management methodology is considered as the basic instrument of developing and forming competitive advantages. Therefore, creation of a knowledge management system and transfer of this knowledge from the wildlife to the methodology of project management, project portfolio management and organization programs management is an advanced area of research. Involving the knowledge of genetics into building up the project product structures, management methodology and project implementation mechanisms will allow using a double spiral structure as a carrier of knowledge about the project product and methodology of an organization projects management. Such a structure permits dividing the knowledge of methodologies into classes and using this knowledge in building efficient project management methodologies adapted to specific activities of the organization and classes of projects and programs.

Organization development projects have a huge number of various features depending on the vector of its condition, lifecycles of the product, technologies, systems of management and business, as well as the effect of surrounding environment. That is why specific conditions typical for organizations where the projects are implemented have an essential impact on the process of formation of these features. Management methodologies, tools and required resources are determined for each project depending on the level of technical maturity and competence of the organization [2].

Far from every organization development project comes to the successful end. Initializing organization development projects, the project team forms the vision, structures and adapts the project to the organization and to the environment. Therefore, the lack of an instrument of transferring the project technology and knowledge from one organization to another and mistakes of project managers result in projects failure. Moreover, such factors as imperfect legislation, lack of efficient universal methodologies and means of project management, as well as ways of resolving the project problems, formation of the project team with account taken of the human factor, psychological barriers have a significant impact on the projects and programs success. All this in general confirms a high degree of changeability of the remote and close environment of projects and a high level of uncertainty and risk in projects when the need for investments is big and the market of labor and services is still relatively cheap. 
Therefore, implementation of methods, models, means and instruments of innovative technologies in organizations development programs management provides opportunities to finish the projects implemented in organizations in proper time and with success.

According to the convergence hypothesis, if the management object is situated in the initial stage farther from the steady balance position, the speed of its development will be higher that of a system being situated closer to the balanced condition. Accordingly, in a long-term period, the differentiation can be smoothened.

The problem considered in this article is related to building of a convergence model and application of knowledge of genetic mechanisms of wildlife to project management systems.

Purpose of the article. The purpose of the article is to create a genetic model of methodologies of managing projects, programs and project portfolios in organization, structuring the knowledge of project management to enrich the methodologies with the knowledge accumulated by the wildlife.

1. Analysis of achievements and publications. Rapid development of the project management both as a science and as an application practice is urgently required today to ensure and to support competitiveness of domestic organizations. The world practice has already formed a huge range of knowledge and methodologies, many of which contain unique models, methods and mechanisms of management borrowed from other subject domains of knowledge. This confirms the possibility and reasonability of using the principles of transferring the best practice and convergence of methods and models for further development of mechanisms of successful implementation of projects and programs. In the process of creating new methodologies, benchmarking technologies and transferring the best practices are widely used which are not always sufficiently grounded and have a clear system of integration and harmonization for their practical implementation.

Using the methods of benchmarking in project management is proposed in [3], where we can see a systemic approach to transferring the know-ledge to project management systems. This confirms the possibility and good prospects of developing benchmarking and convergence, but also raises the problem of their further integration and adaptation in existing standards of project management.

In this case, there is a danger of reducing these technologies to copying various methodologies from various systems without a deep analysis of their applicability in various conditions, incorrect practical application by various players for untypical objects of project activities management.

Such situation may result in a growth of methodological entropy in the project management domain. Project managers will not be able to use unclearly described instruments and it will be very difficult to finalize their study on their own due to the need for additional knowledge and research which is a big science-intensive process. 
Therefore, benchmarking and analogy methods are the instruments requiring further development of methods and models of convergence and integration of transferred methodologies and their scientific and practical groun-ding at formation of new, more efficient systems of knowledge, approaches and methodologies of the project management.

The main purpose of applying convergence of methodologies - is the synergy of elements of the methodologies approaching and harmonizing during the development of the methodology of managing projects, programs and portfolios.

The number and the variety of modern project management methodologies allow considering such methodologies as instruments providing competitive advantages in development of organizations. In this case, technologies of benchmarking and convergence are actively used [5; 7].

2. Classification of models and methods of benchmarking and convergence of the knowledge on project management methodologies. The analysis of modern project management methodologies shows that the mechanisms of benchmarking and convergence of project management methodologies can be represented in the form of a two-level structure: classes and groups [6].

Let us consider the structure of mechanisms of convergence of the project management methodologies. The classes of benchmarking and convergence mechanisms are given on Fig. 1.

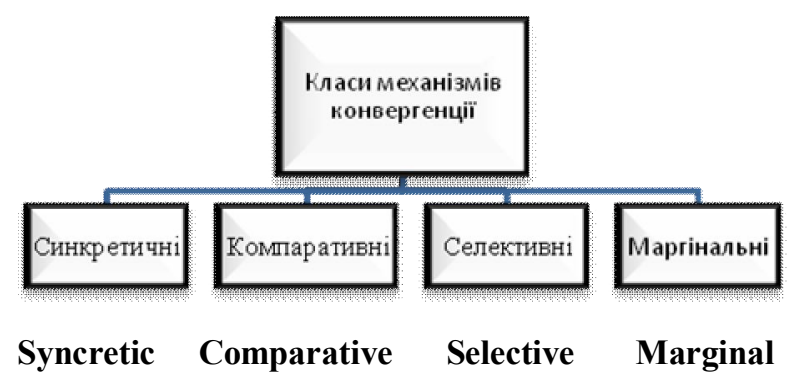

Fig. 1. Classes of mechanisms of benchmarking and convergence of project management methodologies

Syncretic (holistic) mechanisms result in such types of convergence, when different methodologies join each other in a unified undivided variant actually being a creation of a new methodology by means of direct mutual penetration.

Syncretic mechanisms include such groups of mechanisms as:

- additive;

- ambivalent;

- absorptive;

- agglutative. 
Additive mechanisms accumulate the knowledge of methodologies by adding it. In additive mechanisms, the basic methodology is added by other methodologies. That is why they are called complementary. Additive mechanisms tracking the accumulation and methodological enrichment in dynamics can be called amplificative (magnifying) mechanisms.

Ambivalent mechanisms combine opposite approaches. For instance, the method of synthesis with analysis (analytically - synthetic mechanisms); inductive and deductive methods.

Absorption mechanisms are the mechanisms of mergence.

Agglutative mechanisms - join the unchanged basis, merger of two or more methodologies. These mechanisms of «glueings»- mechanisms removing the methodological gaps; they can be conditionally called mechanisms of «patchwork blankets».

In convergence, the patchwork blanket mechanisms can be opposed to stigmatic mechanisms in which merger of methodologies results in an entire, complete and uniform methodology.

The class of comparative mechanisms is characterized by the following groups:

- alternative;

- isomorphic;

- alteration;

- relativistic.

Alternative mechanisms provide widening of the methodological field due to consideration and inclusion of alternative variants to the convergence methodology. Mechanisms of constructive parallelism can be referred to the same group which provide symmetric consideration with subsequent convergence or two or more methodologies.

Isomorphic mechanisms are built on the principle of replacement. For instance: new versions of methodology replace the old ones. In this process, the replacing mechanisms are convergent.

Alteration mechanisms are built on the principle of alteration. These mechanisms are similar to mechanisms of creating network methodologies: convergence mechanisms that are able to create resulting methodologies resolve matrix or network methodological tasks.

Relativistic mechanisms belong to the class of comparative and are relatively highly-complex as compared to the other mechanisms.

The selective mechanisms:

- antilogic;

- mediated;

- amplicative (amplificative);

- casual;

- situational.

Antilogic mechanisms are realized through convergence retrospectively 
to the methodologies selected.

Mediated - is a mechanism of convergence of one methodology, «interdependent» (mediated) through one or several other methodologies.

Amplicative mechanisms are used for strengthening some (as a rule, weak or unclearly expressed) features of a methodology through convergence from other methodology(-ies) possessing systemically worked out new features.

Casual - convergence mechanisms causually linking two or more methodologies for resolving the general methodological task.

Situational mechanisms determine application of convergence depending on internal and external methodological circumstances. In fact, these mechanisms are marginal. They are divided into the following groups:

- accentocentrical;

- asymmetrical;

- occasional;

- extrapolational.

Accentocentrical mechanisms include the mechanisms having special focus on resolving the set methodological task.

Asymmetrical convergence mechanisms result in creation of oppositely adding methodologies.

Occasional mechanisms use convergence for a certain case that is determined by a set of circumstances, purposes and methodological tasks.

Extrapolational mechanisms are realized through selection of two or several unidirectional methodologies with continuation (extrapolation) of these methodologies into the domain of parameters situated beyond the domain of effect of the output methodologies.

3. Building principles of project management systems and organizations development program. The main principle of building programs and projects management methodologies is the Ashby principle [4] - of necessary variety of models and mechanisms. In our case, the purpose of project management is reducing the entropy as a measure of uncertainty, i.e. the law of necessary variety says that the variety (entropy) of project implementation can be reduced no more than by the amount of quantity of the information about the project in the managing system that is equal to variety (entropy) of management less the loss of information from ambiguous management. Or in other words, the bigger the variety of the managing effect and the smaller the losses from ambiguous management, the better the management.

The principle of coherence of methodologies is determined by reaction of the management system to threats in the real time as regards the project safety.

The principle of «convergence, integration and harmonization» of methodologies is related to creation of an efficient project management 
methodology withstanding internal and external negative impacts and threats. In this case, various mechanisms approach the single methodology, integrate and then harmonize themselves from the point of view of possible gaps and overlappings.

The principle of focus on the result and on the product is traditional for the project management. This principle is adding the previous principles for the purpose of forming the integrated mechanism of achieving the goal [6].

4. Basic definitions of using genetic models in creation of project management methodologies. Let us give the basic definitions as regards application of the genetic approach in the project management. These definitions use analogies from biological systems based on approaching of the structured and functional knowledge [7;8].

Definition 1. Genetic model of the project product (product DNA) - is a systemic model describing the project with all heritable characters including the initial imagination on the project product «vision» that is built for the whole lifecycle of the project, instruments of its interaction with the surrounding environment.

Definition 2. Genetic model of the project management methodology (process DNA) - is a systemic model describing the project management processes with all heritable characters including the initial imagination on the project product «vision», integrated process of management in a certain subject domain, build for the whole project lifecycle, instruments of its interaction with the surrounding environment. If the constructed genetic model of methodology is certain, the possibilities of the head of the organization development program get widened.

Definition 3. Phenotype - is a set of external quantity features of the project observed with account taken of the stage of adaptation to the surrounding environment forming the general imagination of the project.

Definition 4. Gene - is a project element (DNA fragment) represented in the phenotype moving from project to project and is a localized information structure forming the steady impact on the environment of projects and programs. Genes are units of heritable material. The length of genes can be the same or different.

Definition 5. Chromosome - is a set of genes of the project product and projects management methodology determining the project qualities (project features, characteristics, class, types, temporary parameters of the project, levels of the project complexity, the project scale, structures of the project lifecycle, external factors of the impact on the project, levels of project flexibility, levels of the project manageability, etc.). The chromosome has a fixed length. Location of a certain gene in the chromosome is called locus, and alternative forms of one and the same gene located in the same locuses of the chromosome are called alleles.

Definition 6. Ribosome (management system RNA) - is a mechanism which, based on the chromosome, performs functions of interpretation of 
actions programmed in genetic models of the product and the project management methodology. The ribosome is a part of the cell consisting of the basic unit rRNA, matrix memory mRNA and transportation structure tRNA.

Definition 7. Genetic code of the project (genotype) - is a certain set of interrelated structures containing all the heritable information received from «ancestors» to be transferred to «descendants». The genetic code of the project is formed at the moment of the project birth, but the most common case is when the code is formed chaotically, based on intuition and practice of managing projects of such class. In the course of the project implementation, the code can be modified under the impact of changes and development of the knowledge on the project product, management processes and interaction with the environment. Finite set of all admissible genotypes creates a gene pool.

Going forward with application of analogies of managing projects in the domain of genome models, let us select two additional genomes - the project competences genome and the project manager's competence genome. These two genomes are crossing at the point where the project competences are realized due to the competence of the project manager. Such interaction forms the project «chromosome». All chromosomes contain a long DNA chain (in the project management, this is structured knowledge in the form of a triple spiral) containing genes, regulatory elements and intermediate sequences in creation of the project product.

Defining the strategies of implementing innovative programs of development of organizations due to the genetic approach helps to build efficient systems of managing projects, programs and project portfolios of financial organizations the idea of which is based on gradual improvement of composition of the population based on natural selection of the project elements during formation of organizations development programs. The approaches permits quickly assessing all types of projects within the frames of restrictions applied. Depending on the strategy of innovative programs, the level of project «here-dity» and «changeability» is determined to disclose the essence of how each phase of the project lifecycle reproduces itself in a new project, and how «heritable changes» appear in these conditions. «Heredity» and «changeability» are the two sides of the same lifecycles of the project.

Heritable changes are connected to the process of creating new project elements and changeability is related to the process of destruction of the old elements of the project.

5. The model of benchmarking of genetic information in the project management. In the course of project implementation, the genetic code can be modified under the effect of changes and development of the system of knowledge about the project product, the processes of management and interaction with surrounding people. Let us consider the conceptual model of genetic mechanisms in the management of projects and programs. Application of genome imaginations of management methodologies with account taken of the existing problems of organizations, turbulence of the inner 
and outer environment. We divide the problems into four groups: determination of purpose, achieving of goal, organizational competence and organizational behavior.

Let us consider the mechanisms of formation of proteins in the wildlife as analog of creation of project products [8; 9]. We use analogies with the ribosome which is a part of the cell consisting of rRNA, mRNA and tRNA. The rRNA type that is the central component of ribosome collecting proteins (resources) in the cell (the protein product). The function or rRNA is to ensure the mechanism for decoding the matrix memory of mRNA and interacts with tRNA during translation of the information ensuring the activities of the ribosome mechanism. So the ribosome makes synthesis of the project resources and the project product translating them from the mRNA memory. The ribosome can be considered as a plant producing recourses and parts of the project based on the existing genetic information. In the project, ribosomes are mainly situated in compartments for active synthesis of resources. The active ribosomes (those present in the translation process) are mainly presented in the form of polysomes.

The ribosome is a mechanism for translation of genetic information encoded in the mRNA matrix memory. This information is materialized in the synthesized product of the project. The ribosome bears dual information: it is a structural platform for the process of decoding genetic information from RNA and it possesses a catalytic center responsible for formation of the project product.

Let us consider the functions of the ribosome.

Translation - synthesis of proteins from amino acids (in case of projects of resources and results of the project) that is catalyzed by the ribosome on the model of matrix RNA (mRNA). Translation is one of the stages of creation of the project product (biosynthesis of proteins) and it is, it its turn, a part of the process of genes expression. During the translation, the information contained in mRNA is decoded according to the rules known as the genetic code and used for synthesis of encoded sequence of elements. The translation pro-cess can be divided into four phases: activation, initiation, elongation and termination.

We consider the mechanism of translation. Itiniation of translation provides for cognition of codon by the ribosome and involving the initiative transportation tRNA. For initiation of translation, there is also a need for presence of certain sequences of creating the project product in the area of the starting codon. This mechanism helps to translate the major number of mRNA.

These are not only mRNA who takes part in the processing, but also many other types of non-coding RNA, transportation RNA and ribosome RNA. The diagram of formation of the project product based on the convergence of the mRNA knowledge is given on Fig. 2 .

Let us consider some processes of formation of project products based on matrix RNA. 


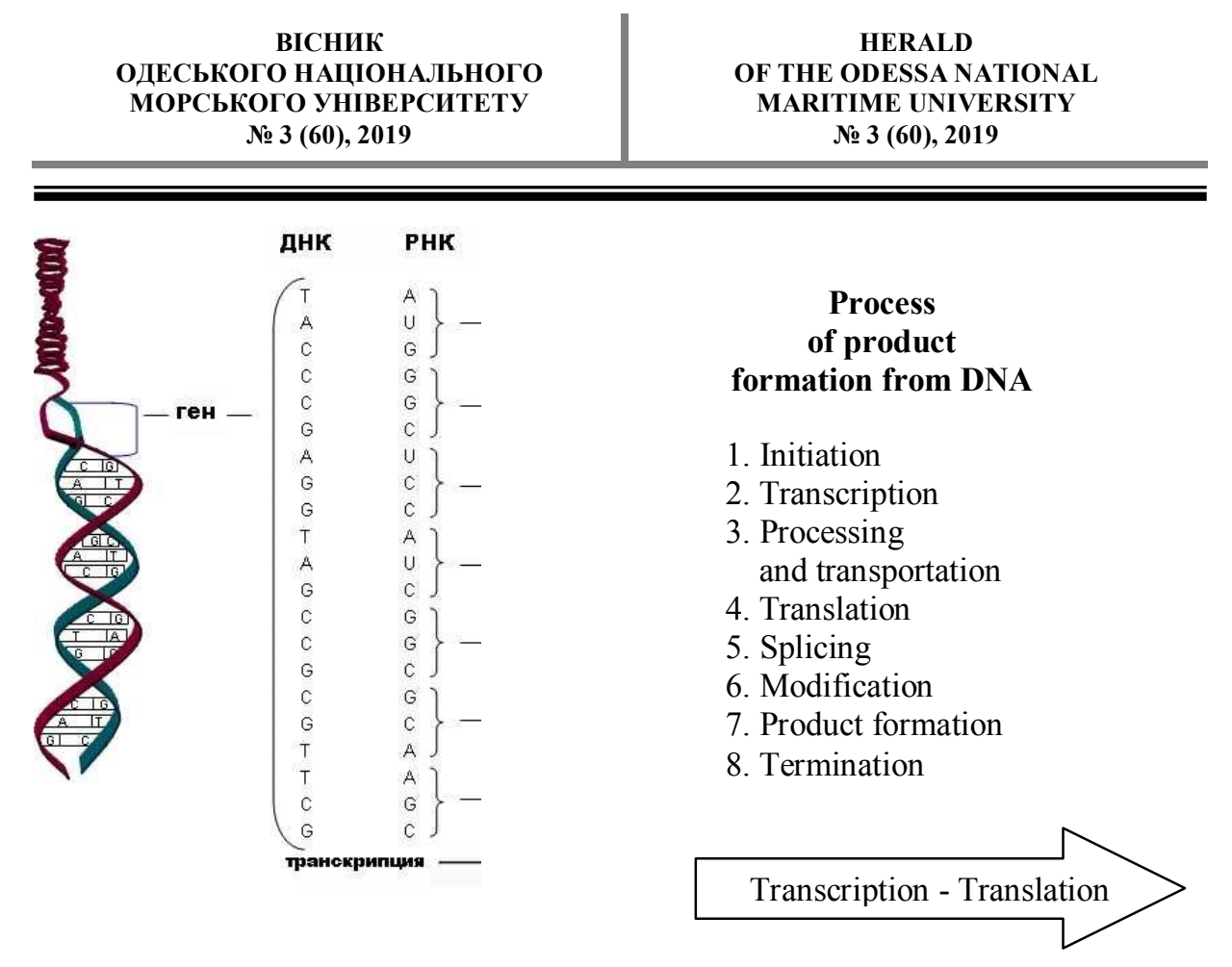

Fig. 2. Diagram of product formation based on DNA-mRNA

Transcription. Certain parts (genes) of two-stranded DNA are matrix for the synthesis of one-stranded RNA chains on them. Synthesized RNA chains are complementary to one of the DNA chains and, accordingly, they exactly reproduce the desoxyribonucleotide sequence of the other DNA chain in its ribonucleotide sequence.

RNA processing and transportation. During the synthesis and after it, especially in the cell, RNA can be subjected to a number of additional changes (adding of end groups, modification of nucleotides, cutting off certain pieces of the nucleotide sequence, etc.). The outgoing informational or matrix RNA (mRNA) further arrive at ribosomes (is transported to eukaryote from the nucleus to cytoplasm) as a program which determines the amino acid sequence in protein synthesis. Then the amino acids are activated and accepted. The outdoing material of which protein is built are amino acids. However, free amino acids of the cell cannon be directly used by the ribosome. Each amino acid is activated first with the help of ATP and then added to the special RNA molecule, so called transportation RNA (tRNA) outside ribosomes. The outgoing aminoacyl-tRNA arrives at the ribosome as a substrate for synthesis of protein.

Translation. The flow of information in the form of mRNA and the flow of material in the form of aminoacyl-tRNA arrive at ribosomes which are molecular machines making the translation of genetic information from the language of nucleotide mRNA sequence into the language of amino acid sequence and synthesized by the polypeptide protein chain. Each ribosome in sequence scans the mRNA chain (moves along it from one end to another) and 
selects accordingly those aminoacyl-tRNA which correspond with complementary triplet combinations of nucleotides situated in the ribosome at the moment. In this way, the movement of the ribosome along the mRNA creates the strict temporary order of entering the ribosome by various aminoacyl-tRNA according to the order of order of location, nucleotide combinations (codons) are encoded along the mRNA. The amino acid residue of the reverse aminoacyltRNA is every time covalently added by the ribosome to the increasing line of polypeptide chain and the deacylated tRNA is released from the ribosome into the solution. This is the principle of building the polypeptide chain residue by residue.

Formation (of project product) of functional protein. As far as the synthesis process goes, the polypeptide chain is partly used from the ribosome and begins to be folded into the globule (co-translational folding), and at the end of the synthesis, i.e. after reading of the whole mRNA, it is released from the ribosome and finally folded (posttranslational folding). The synthesized protein can be transported through cell membranes which is typical for proteins produced by the cell for general needs of the organism or a cell population (secretion of proteins). The protein folding and protein transportation through membranes can be accompanied by various covalent modifications with the help of ferments (protein processing). Therefore, the process of creation of a chemical structure of protein (synthesis of polypeptide chain) and, to a significant extent, its physical folding into a functionally active protein globule is realized by the ribosome. The number of ribosomes in a cell is strongly varying from thousands to tens of thousands per one cell - depending on intensity of the protein synthesis in this type of cells. Each ribosome completely reads one mRNA molecule and synthesizes one protein molecule according to its program. After this, it can be programmed by other mRNA molecule and produce another protein molecule, etc. As a rule, one mRNA molecule is read by several ribosomes at a time moving along the mRNA one after another and so independently synthesizing identical protein molecules, but with respective delay. Such dynamic complex of one mRNA with several ribosomes is called polyribosome. In the process of work, a ribosome consumes energy from hydrolysis of guanosine triphosphate (GTP).

Summary. The models and methods of benchmarking and convergence of knowledge as regards the application of genetic mechanisms of wildlife have been determined. Classification of mechanisms of benchmarking and convergence of knowledge of different domains has been proposed.

Four principles of formation of project management methodologies based on convergence and benchmarking have been provided. The basic definitions of application of genetic models in creation of project management methodology in the process of benchmarking have been given.

The model of benchmarking of genetic mechanisms based on informational ribosome (mRNA) for the purpose of convergence of knowledge of genetics in the project management methodology has been proposed. 


\section{REFERENCES}

1. Individual competence baseline for Project, Programme and Portfolio management (IPMA ICB). IPMA. Version 4.0. 431 p.

2. IPMA Organisational Competence Baseline (IPMA OCB). IPMA, 2013, $67 \mathrm{p}$.

3. Creative technologies of project and program management: [monograph] / [S.D. Bushuev, N.S. Bushueva, I.A. Babaev, V.B. Yakovenko and etc.]. K.: Summit-Book, 2010. 768 p.

4. Ashby U. Introduction into cybernetics, Foreign literature. M., 1959. $428 c$.

5. Bushuyev Sergey D., Wagner Reinhard F. IPMA Delta and IPMA Organisational Competence Baseline (OCB): New approaches in the field of project management maturity, International Journal of Managing Projects in Business, Vol. 7, 2014 Iss: 2, pp.302-310.

6. Bushuev S.D. Mechanisms for the convergence of project management methodologies. [Text] / S.D. Bushuyev, N.S. Bushuyeva, S.I. Neizvesnyy // Managing the development of complex systems. 2012. № 11. p. 5-13.

7. Bushuyev S.D. Development of innovation methods and models of project management on the basis of convergence [Text] / S.D. Bushuyev, M.S. Dorosh // Managing the development of complex systems. 2015. № 23. pp. 30-37.

8. Bruce Alberts, Alexander Johnson, Julian Lewis, Martin Raff, Keith Roberts, Peter Walter. Molecular Biology of the Cell.5. Garland Science, 2008. 1392 c.

9. Modern problems of biochemistry. Research methods / E.B. Barkovsky and others. Minsk: High School. 2013. 491s.

\section{СПИСОК ЛІТЕРАТУРИ}

1. Individual competence baseline for Project, Programme and Portfolio management (IPMA ICB). IPMA. Version 4.0. 431 p.

2. IPMA Organisational Competence Baseline (IPMA OCB). IPMA, 2013, $67 \mathrm{p}$.

3. Креативные технологии управления проектами и программами: [монография] / [С.Д. Бушуев, Н.С. Бушуева, И.А.Бабаев, В.Б. Яковенко и др.]. К.: Саммит-Книга, 2010. 768 с.

4. Эшби У.Р. Введение в кибернетику, Иностранная литература, Москва, 1959. 428 c.

5. Bushuyev Sergey D., Wagner Reinhard F. IPMA Delta and IPMA Organisational Competence Baseline (OCB): New approaches in 
ВІСНИК

ОДЕСЬКОГО НАЦІОНАЛЬНОГО

МОРСЬКОГО УНІВЕРСИТЕТУ

№ 3 (60), 2019
HERALD

OF THE ODESSA NATIONAL

MARITIME UNIVERSITY

№ 3 (60), 2019

the field of project management maturity, International Journal of Managing Projects in Business, Vol. 7, 2014 Iss: 2, pp.302-310.

6. Бушуев С.Д. Механизмы конвергенции методологий управления проектами. [Текст] / С.Д. Бушуев, Н.С.Бушуева, С.И. Неизвестный // Управління розвитком складних систем. 2012. № 11. C. 5-13.

7. Бушуєв С.Д. Формування інновачійних методів та моделей управління проектами на основі конвергенції [Текст] С.Д. Бушуєв, М.С. Дорош // Управління розвитком складних систем. 2015. № 23. С. 30-37.

8. Bruce Alberts, Alexander Johnson, Julian Lewis, Martin Raff, Keith Roberts, Peter Walter. Molecular Biology of the Cell. 5. Garland Science, 2008. 1392 c.

9. Современные проблемы биохимии. Методы исследований / Е.В. Барковский и др. Минск: Высшая школа 2013. 491 .

Стаття надійшла до редакиії 10.12.2019 